for the job to make yet another detailed two-year study of technical, commercial and economic factors affecting the Channel Tunnel. It is intended that the study will then form the basis for final decisions on the proposed rail tunnel, which would be built by private enterprise and run by a public organization whose financial undertakings would include the remuneration of the companies concerned.

Locations for the rail terminals at the English end of the tunnel have already been discussed, after an examination in 1968 by a group based on the Ministry of Transport. Ashford in Kent was first marked out as a possible site, but now it seems that locations nearer the coast are more favoured. Three kinds of terminal would be required, the largest of which would be a ferry terminal for transferring vehicles to the trains that would take them through the 35 miles of tunnel. The other installations would be a railway passenger station and a freight yard. No decisions have been made about the final siting of any of these, but there are half a dozen sites in Kent which look promising.

The tunnel itself, which could be open in 1976 if all went well, would run from near Folkestone to a point in France near Calais and use $25 \mathrm{kV}$ overhead electrification. Ferry trains would carry up to 300 road vehicles, and would run a frequent shuttle service; other traffic would include through freight and passenger trains from centres in Britain to many continental destinations.

Alternatives to the tunnel are not likely to meet with much success now, in view of the official commitment to a rail link under the Channel, although there is always Stansted Airport to be borne in mind as an example of a last-minute change. All would depend on how far a rival suggestion could win popular support on a large scale. Devoted readers of Nature may remember a competition at the end of last year to design a dam for the Channel; another approach, advocated by a number of academics including at least one engineering professor, involves a combined bridge and tunnel, and the success of a project of this kind in Chesapeake Bay in the United States has prompted the Institution of Civil Engineers to invite General L. J. Sverdrup (chairman of the firm of consultants that designed the scheme) to give a lecture in London on September 29 about the project.

The interesting point here is the use of four artificial islands as points of interchange between sections of bridge and tunnel. Two tunnels, each over a mile long, run beneath important shipping channels and the remaining gaps are crossed by bridges. Because one of the main objections to a Channel bridge is that it would take too long to negotiate suitable agreements among the eighty or so nations whose maritime activities would be affected, this design looks at first sight attractive. It falls down, however, on cost. A study group in 1962 reported that a bridge-tunnel combination might be more than three times as expensive as the rail tunnel.

What is rather more relevant, if less exciting, is the method that the American engineers have used to build the tunnels. Concrete tubing is lowered into a trench across the sea floor which is then filled to a depth of at least five metres. This is one of the two techniques considered for the English Channel, the second being the traditional boring of holes from each end to meet in the middle. According to the Ministry of Transport, the immersed-tube illea has not been rejected, and the final decision may therefore, it seems, rest on fairly fine points.

\section{INTERNATIONAL MEETINGS More Food Not Enough}

\section{from our Botany Correspondent}

Delegates to the eleventh International Botanical Congress in Washington earlier this month joined the ranks of those who feel that the solution to world food problems can come only through population control. When the botanists' contribution to increasing food supplies was discussed, a minority of delegates felt strongly that no amount of effort would be adequate. This group left its mark on the final wording of the first resolution passed by the plenary session of the congress on September 2, to the effect that members of the congress, conscious of their responsibilities as biologists, considered that there can be no solution to the food problem unless population control is achieved. The resolution went on to urge governments to adopt appropriate policies, at the same time ensuring an adequate standard of living for their people, particularly by encouraging the increased food production which goes with proper land use.

Further mindful of their responsibilities as biologists, the delegates passed an all embracing resolution urging individuals and organizations interested in conservation to do all in their power to preserve the Earth's biosphere from the destructive influence of men. The resolution also urged governments and other organizations to support the conservation projects of the International Biological Programme and those that are within the ambit of the International Council of Scientific Unions and the International Union for Conservation of Nature and Natural Resources. The delegates evidently had no difficulty in reaching unanimous agreement on this topic. But the obvious problem with such a resolution is that it will be extremely difficult to put into effect.

A practical step may be the setting up of an environmental biology section within the International Botanical Congress. A third resolution passed on September 2 urged the planning committee for the next congress, to be held in Leningrad in 1975, to make provision for sessions devoted to the problem of the deterioration of the environment. Whether or not the new section is set up remains to be seen. The general feeling was that the organizers of the next congress should not be restricted by any resolution passed now, and so environmental biology may or may not form an official part of the proceedings in Leningrad.

\section{SCIENCE EDUCATION}

\section{Soviet Prizes and Problems}

\section{from a Correspondent}

THE opening of the new academic year has, as is customary, been hailed by the Soviet Press with reviews of the current achievements in Soviet education and plans for the immediate future. Much of the discussion has been concerned with the relationship of current 
educational policy to the directives of the most recent (Twenty-Third) Party Congress, which stressed the need for a considerable increase in the economic level and prosperity of the peoples of the Soviet Union and for a speeding up of the industrialization of Siberia, the Soviet Far East and other less developed regions.

Among the rash of newly opened and projected educational and scientific institutions, the emphasis seems to lie largely on the applied sciences. The new developments of the Donets scientific centre of the Ukrainian Academy of Sciences include, alongside a new Institute of Applied Mathematics, the somewhat specialized Institute of Industrial Economics. At the other end of the Union, at Irkutsk, the new "science village" of the East Siberian Branch of the Siberian Division of the Academy of Sciences of the USSR specializes in geology, biology, chemistry and power engineering-all of which have specific applications to the development of the region. Vil'nyus (Lithuania) has a new Institute of Building Engineering, Vitebstk (Byelorussia) a new trade training Technikum, while there is also interest in the new State University at Yaroslavl (due to receive its first students in 1971).

It would seem, however, that this scheme of education for industry and technology is not entirely bearing the hoped-for fruits. A brief and somewhat vague note in Pravda (August 8), reporting the meeting of the Commission on National Education, Science and Culture, urges, in general terms, "improvement in the training of specialists in the field of economics in Higher and Secondary colleges". In a leader of September 3, Pravda becomes even more explicit. Speaking of the "science centres" scattered throughout the Union and related, according to current policy, to the local industrial and natural resources, it states: "It is no secret, for example, that a number of the branches still have an insufficient experimental basis, and are suffering from lack of living accommodation for the scientific personnel, in laboratory and auxiliary buildings". Similarly, at the same time as the importance of primary and secondary education as the basis for the technology of the future is being reiterated in the Press throughout the whole Soviet Union, and new education schernes are being inaugurated such as the new schools television project in the Byelorussian SSR, designed to give instruction in the "methods of the scientific disciplines and the latest achievements of science", many schools-the regional boarding schools particularly-are suffering acute shortages of educam tional equipment and living facilities. In the words of the Pravda leader-writer, "a good material basis is the most important condition for increasing the effectiveness of scientific work". It would appear, therefore, that, before science training can come to the aid of Soviet economic development, the Soviet economy must come to the aid of at least certain educational establishmentis.

\section{MANPOWER}

\section{Brain Drain Office Repatriated}

REVERSING the brain drain is a tough proposition. It is certainly a bigger proposition than the Ministry of Technology foresaw when in 1967 it awarded a contract for $£ 85,000$ to Management Selection, Ltd. (MSL), for a recruitment campaign to lure back to Britain some of the qualified people who had left for America. It is probably a greater task than MSL itself realized, because last month it shut down its New York recruiting office.

The office was opened in September 1967. It seems to have been a mixed success. MSL claims to have been instrumental in placing in British companies about 500 people from American firms and universities with HNC or higher qualifications. This figure has been estimated from follow-up records of about three hundred people from a total list of 900 . These show that 70 per cent accepted appointments in Britain, and 27 per cent took up fresh appointments abroad. An average of 250 people recruited a year is substantially better than any similar scheme has achieved, but, when compared with the figure of 3,100 scientists and technologists who left Britain for America in 1966, it does not exactly reverse the flow. However, MSL claims that the contacts and expertise built up during this period in New York will be invaluable if British industry is ever going to make a significant impact in luring back its departed scientists and technologists. The contract is due to expire in March 1970 , and discussions are now going on about possible extensions of the work.

MSL says that shutting down the New York office does not indicate that the project has failed, and that it will be more efficient if all the work is done in London. Given a free choice, more than 80 per cent of applieants wrote to London and not New York. All the advertising is run from a London agency; while a London base will enable MSL to concentrate more on the recipient companies.

The method which MSL has been using is to provide a link between British firms and people working in America through advertisements, direct contact by letter and through the Transatlantic Newsletter, a bulletin of job opportunities which has a readership of about four thousand. These methods are similar to those employed by the North American Joint Selection Board, which has been operating for about ten years and recruits specifically for the Scientific Civil Service, the Atomic Energy Authority and the Central Electricity Generating Board, but the standard of the people accepted in the NAJSB scheme and the rigour of the interview probably account for the fact that only about five hundred people have been recruited since the scheme started (see Nature, 220, 645; 1968). Both schemes seem to share the property of recruiting people who have already decided that they want to return to Britain and who need some sort of push.

The reason given for returning is usually intangible, stemming from a difficulty in identifying with a foreign community. The average salary change of the people who were handled by MSL was from $\mathfrak{f 5 , 7 5 0}$ to $\mathfrak{f 2}, 900$, which shows that salary considerations took second place.

INTERNATIONAL ORGANIZATIONS

\section{European Geophysical Union}

\section{from our Geomagnetism Correspondent}

DURING the recent general assemblies of IAGA and IASPEI (see page 1207) in Madrid (September 1-12), two meetings were convened by Professor S. K. Runcorn (University of Newcastle upon. Tyne) to discuss the 